\title{
BAHASA PANTUN DALAM MAKNA DAN BUDAYA MASYARAKAT ME- LAYU BANGKA: SEBUAH KAJIAN ETNOLINGUISTIK
}

\author{
Dini Wulansari \\ Program Studi Sastra Inggris, Fakultas Ilmu Sosial dan Ilmu Politik
}

\begin{abstract}
"Pantun Melayu Bangka" is one of the cultural heritages of Bangka Island and has become a unique identity for its people. This descriptive-qualitative study aims to describe and to explore the "pantun" as a picture of the Island's condition. Data were analyzed by ethnolinguistics approach and supported by socio-cultural values in the form of linguistics characteristic and life reflected in the words, signs, or symbols. Therefore, ethnolinguistics plays an important role in this study not only in determining and relating the use of language and the meaning of "Pantun" itself but also in understanding the cultures. "Pantun" yields an interesting and effective way to make a person think and interprete any ideas logically and artistically as well with the proper diction and harmonization.
\end{abstract}

Keywords: Pantun, Melayu Bangka, Ethnolinguistics, Semantics

\section{PENDAHULUAN}

Pantun adalah salah satu karya sastra rakyat yang bernilai seni dan penuh pesan moral didalamnya. Pantun tidak hanya memiliki unsur-unsur teoritis seperti bentuk, fungsi, karakteristik, dan struktur namun juga didukung oleh nilai sosial budaya sebagai ciri khas kebahasaan dan kehidupan masyarakatnya yang tercermin melalui kata, tanda, lambang, atau simbol tertentu. Mengungkapkan berbagai hal secara tidak langsung dan agar makna yang ingin disampaikan tetap sopan dan santun merupakan bagian dari penggunaan pantun dalam kehidupan sehari-hari seperti yang diterapkan oleh masyarakat Melayu Bangka secara turun-temurun. Pantun telah mengakar dalam kehidupan mereka sebagai warisan budaya yang berisikan nasihat, teka-teki, humor, cinta, bahkan mantera yang dikemas dengan apik sehingga dapat digunakan baik dalam situasi formal maupun informal.
Pantun dipilih sebagai objek kajian karena produk budaya ini dinilai mulai terkikis oleh perkembangan budaya barat. Gejala dan fenomena yang muncul menunjukkan bahwa tidak hanya pemanfaatan pantun dalam acara-acara tertentu di masyarakat Melayu Bangka namun juga di daerah-daerah lain yang semakin menurun bahkan dianggap sebagai hal yang susah untuk dilakukan.

Secara teoretis, struktur pantun sama seperti pantun lainnya yang terdiri atas empat baris dengan ketentuan bahwa dua baris berupa sampiran dan dua baris isi. Isi pantun merupakan inti atau maksud pantun dengan rima (persajakan). Menurut Herfanda (2008) dalam Nurhayati (2011) bahwa rima pantun merujuk kepada dua baris sampiran di atasnya. Dengan kata lain, pantun merupakan karya sastra yang terikat oleh unsur sampiran, isi, rima, dan jumlah suku kata per baris yang berperan sebagai alat pemelihara bahasa dengan menjaga fungsi kata dan kemam- 
puan berpikir, serta memiliki fungsi pergaulan yang sangat kuat secara sosial (Ratih: 2012). Fenomena kebahasaan ini menunjukkan adanya relasi antara bahasa, makna, dan budaya sehingga membuat kajian pantun berada pada tataran etnolinguistik yang berfungsi sebagai landasan teori dan payung analisis.

Pengkajian dengan tema makna dan budaya juga telah dilakukan oleh beberapa peneliti sebelumnya antara lain: Yudi Handoko Himawan (2012) dalam tesis yang meneliti tentang Lelakaq dalam budaya Sasak. Penelitian tersebut berusaha menemukan makna dibalik tanda-tanda kebahasaan untuk mengungkap cakrawala budaya yg terkandung didalamnya. Nurhayati (2011) dalam artikelnya berjudul "Penggunaan Pantun dalam Bahasa Melayu Bangka" mengkaji pantun dari sisi stilistika. Melalui kajian stilistik dapat diketahui penggunaan bahasa dalam pantun, perlakuan pemantun terhadap konvensi pantun, dan sekaligus makna yang terdapat di dalam pantun itu sendiri. Sedangkan Akhmad Elvian (2009) dalam makalahnya membahas tentang peran organisasi sosial suku bangsa Melayu Bangka sebagai kearifan lokal dan kekuatan sosial dalam penataan dan pembangunan masyarakat.

Tujuan yang paling mendasar adalah diharapkan dapat membantu dalam menafsirkan makna pantun itu sendiri dibalik penggunaan kata, tanda, simbol atau lambang kebahasaannya secara lebih mendalam sehingga mendorong dan meningkatkan kembali rasa bangga berbahasa dan berbudaya daerah, menggambarkan kehidupan sosial budaya masyarakat Melayu Bangka secara menyeluruh agar kelestarian atau pemertahanan penggunaannya dapat berlangsung terus sebagai wujud dari keberagaman budaya, serta dapat menjadi referensi bagi peneliti lain sebagai tambahan pemahaman yang dapat digunakan untuk studi lanjutan.

\section{KERANGKA TEORITIS}

\section{Definisi Etnolinguistik (Linguistik Antro- plogi)}

Kajian yang digunakan untuk menelaah bahasa teks dalam pantun adalah kajian etnolinguistik atau lebih dikenal dengan sebutan Linguistik Antropologis. Foley (1997: 3-5) mengungkapkan bahwa linguistik antropologis (etnolinguistik) adalah cabang linguistik yang mengkaji bahasa dalam kontek sosial dan budaya yang lebih luas dan berperan sebagai penopang perilaku kebudayaan dan struktur sosial. Lebih jauh ia menyatakan bahwa linguistik antropologis memandang bahasa melalui sudut pandang konsep antropologis kebudayaan seperti mencari makna yang tersembunyi dibalik penggunaan kata, kesalahan maupun perbedaan bentuk, register, dan gaya.

Pengertian tersebut menunjukkan bahwa linguistik antropologi (etnolinguistik) bersifat interpretatif yang membahas masalah kebahasaan untuk menemukan bentuk pemahaman budaya yang ada (cultural understanding). Sedangkan Kridalaksana dalam Kamus Linguistik (2011:59) mengungkapkan bahwa salah satu aspek etnolinguistik (linguistik antropologi) yang menonjol adalah relativitas bahasa, yaitu adanya hubungan antara bahasa dan sikap bahasawan/ masyarakat terhadap bahasa itu sendiri.

\section{Pantun Melayu Bangka sebagai wacana}

Menurut Vass (1992) dalam Titscher dkk (2009) mengungkapkan bahwa sebuah bentuk rangkaian pernyataan atau ujaran atau yang berupa arkeologis merupakan sebuah wacana, tidak terkecuali pantun yang merupakan salah satu contoh selain puisi dan wacana ilmiah. Konsep pantun dalam suatu wacana yang terdiri dari kata-kata, kalimat-kalimat, atau frase yang sal- 
ing berkaitan satu sama lain dan kohesif dengan makna yang terkandung di dalamnya yang lazim memiliki empat baris dan dua bagian yaitu sampiran dan isi, serta berakhir dengan pola $a-b-a-b$ dan a-a-a-a.

Pantun Melayu Bangka menggambarkan berbagai hal yang berasal dari kehidupan masyarakatnya seperti kepercayaan (agama, mitos, legenda, dll), tumbuhan, hewan, suku-suku yang ada, makanan khas, dll, dan mencerminkan kehidupan sosial budaya masyarakat setempat yaitu budi bahasa/pekerti, kasih sayang masyarakat, adat-istiadat, mata pencaharian masyarakat setempat, aktifitas masyarakat, sistem kekerabatan, kesenian, pergaulan muda-mudi, dll.

Unsur-unsur tersebut dijadikan referensi dalam menganalisa pantun sehingga dapat mewakili kepribadian masyarakat setempat (masyarakat Bangka) yang merupakan orang Melayu yang terkenal dengan pemikiran dan falsafah tradisionalnya yang tinggi, asli dan bernilai seni, serta kehidupan yang santun dan beragam.

\section{METODOLOGI}

Penelitian tentang bahasa pantun Melayu Bangka ini bersifat deskriptif qualitatif yang lazim diterapkan dalam ilmu linguistik struktural dimana penelitian tersebut dilakukan seobyektif mungkin, semata-mata hanya berdasarkan pada fakta yang ada atau fenomena yang memang secara empiris hidup pada penutur-penuturnya, sehingga yang dihasilkan atau yang dicatat berupa perian bahasa yang biasa dikatakan sifatnya seperti potret: paparan seperti adanya (Sudaryanto, 1988: 62) yang menjadi data lengkap secara tipikal (bukan berdasarkan jumlah) tanpa berusaha untuk dimanipulasi guna memperoleh hasil yang diinginkan. Adapun metode yang digunakan dalam penelitian ini terdiri dari tiga tahap yaitu:

\section{Metode Pengumpulan Data}

Data dalam kajian ini berupa kumpulan pantun Melayu Bangka dari berbagai pengarang/ pemantun yang ada di Pulau Bangka, Propinsi Kepulauan Bangka Belitung baik itu berupa humor/anekdot, nasihat, cinta, teka-teki, muda-mudi, dan budaya. Dari sekian banyak Pantun tersebut dipilih beberapa saja yang dianggap mewakili unsur-unsur/aspek-aspek dalam kajian etnolinguistik ini.

\section{Metode Analisis Data}

Data yang terkumpul dianalisa secara etnolinguistik dengan tidak menghitung jumlah dari objek/sumber kajian namun seberapa jauh dan mendalam data tersebut dapat menjelaskan tujuan penelitian sehingga pada akhirnya target penelitian dapat tercapai dengan baik dan reliable. Pantun diinterpretasikan sesuai dengan kondisi kehidupan sosial budaya masyarakat Melayu Bangka.

\section{Metode Penyajian data}

Hasil dari penelitian ini adalah berupa data-data yang berisikan kaidah-kaidah penggunaan bahasa yang telah dianalisis yang disajikan dengan menggunakan metode informal atau verbal melalui kata-kata atau kalimat, tidak berupa sistem penghitungan atau data statistik. Dengan kata lain, penelitian ini cukup disajikan secara deskriptif dalam bentuk tulisan yang informal menggunakan kata-kata biasa untuk mendeskripsikan hasil analisis data (Sudaryanto, 1993, dalam Himawan: 2012).

\section{ANALISIS DAN PEMBAHASAN}

Membahas pantun memiliki tantangan tersendiri apalagi jika dikaitkan dengan masyarakat yang hidup di daerah dimana pantun tersebut digunakan. Banyak unsur/aspek yang 
harus dihubungkan sehingga menunjukkan koherensi antara objek yang akan dikaji dengan faktor pendukung dari kajian itu sendiri misalnya harus betul-betul mengenal karakteristik ataupun kehidupan sosial budaya dari masyarakat setempat atau bagaimana kondisi dan tradisi yang ada.

Berikut disajikan kajian etnolinguistik terhadap serangkaian pantun Melayu Bangka ditinjau dari bentuk, tema, fungsi, dan karakteristiknya sebagai bagian dari sebuah wacana yang disertai interpretasi terhadap pantun-pantun tersebut:

\section{Interpretasi pantun-pantun Melayu Bangka Pantun I}

Marong kebun, marong uma

Timah, lada, karet beterak

Pasir putih bertahta kaya

Tersebar luas di irak-irak

Pantun I mengungkapkan bahwa pulau Bangka memiliki sumber daya alam yang kaya dan terkenal tidak hanya di Indonesia namun hingga ke mancanegara yaitu timah. Hasil tambang ini merupakan salah satu andalan masyarakat Bangka dan pemerintah propinsi Kepulauan Bangka Belitung sebagai sumber devisa dan sumber mata pencaharian untuk memenuhi kebutuhan hidup sehari-hari baik itu sandang maupun pangan. Banyak orang Bangka (bahasa Bangka: urang Bangke/Bangkek) yang bekerja menjadi karyawan Timah atau penambang timah rakyat baik yang legal maupun ilegal. Jika sebagai karyawan timah maka orang tersebut bekerja pada sebuah perusahaan legal dan besar seperti PT. Timah Tbk dan PT. Kobatin, sedangkan jika sebagai penambang timah legal (bahasa Bangka: pelimbang timah) maka orang tersebut bekerja (bahasa bangka: ngelangkung) pada sebuah perusahaan mandiri yang dikenal dengan sebutan smelter. Pada umumnya pemilik perusahaan adalah para investor asing, namun lain halnya dengan penambang timah ilegal yang bekerja dengan pemilik tambang pribadi (TI inkonvensional) dengan upah tergantung dari seberapa banyak timah yang berhasil diperoleh melalui proses pelimbangan yang terkadang sampai bergelut dengan maut apabila tidak dilakukan dengan konsentrasi dan penuh kehati-hatian.

Seiiring dengan perkembangan zaman yang mengakibatkan semakin bertambahnya kebutuhan manusia, maka semakin meningkat pula kebutuhan akan lapangan pekerjaan. Hal ini berimbas pada membludaknya kedatangan para pencari kerja ke Pulau Bangka yang sebagian besar akhirnya berprofesi sebagai penambang timah ilegal. Selain itu, terdapat juga sumber tambang lain yaitu pasir putih atau kuarsa yang merupakan salah satu komoditi ekspor Pulau Bangka. Pasir ini banyak sekali manfaatnya. Masyarakat Melayu Bangka biasanya menggunakannya untuk membersihkan peralatan memasak yang hitam yang susah dibersihkan dengan deterjen atau sabun cuci biasa. Seperti yang terlihat pada pantun dibawah ini:

Sebelas ribu kilometer persegi

Itulah luas hamparan Bangka

Pulau penyimpan banyak misteri

Dikelilingi indahnya pasir kuarsa

Dapat disimpulkan bahwa Pulau Bangka memiliki hasil bumi yaitu bahan tambang yang kaya yang berguna bagi masyarakat sekitar dan kehidupannya.

\section{Pantun II}

Teluk Kelabat nan gagah berani

Pemberi kekayaan kepada negeri

Sarang sotong, ketam, dan pari

Kubangan tiram dijaga tenggiri

Calo, rusep, perkasem, belacan

Makanan rakyat sampai ke kota 
Nafsu bangkit bukan buatan

Rasa nikmat ngundang selera

Sungguhlah indah pulau Bangka

Orang Kurau memancing krisi

Kalau ada kata yang salah

Jangan simpan di dalam hati

Pantun II menggambarkan Pulau Bangka sebagai sebuah kepulauan yang dikelilingi oleh laut dimana memiliki begitu beraneka ragam binatang laut seperti sotong, ketam, pari, tiram, krisi, dan tenggiri yang digunakan untuk kebutuhan pangan masyarakat sehari-hari. Selain dikonsumsi sebagai lauk-pauk dan dijual, hasil laut tersebut juga dimanfaatkan sebagai bahan dasar pembuatan makanan ringan (snack) seperti empek-empek, kerupuk, kemplang, getas, belacan (terasi), otak-otak, rusep, dll. Penganan ini sangat terkenal di Indonesia dan juga mancanegara yang biasanya dijadikan oleh-oleh bagi para pembeli.

Selain hasil laut, Pulau Bangka juga memiliki ikan-ikan air tawar seperti gabus dan mayung yang banyak terdapat di genangan-genangan air bekas tambang timah terdahulu, di aliran-aliran sungai atau memang secara sengaja dipelihara yang biasanya dapat dijumpai di wilayah perkampungan. Biasanya ikan-ikan ini juga digunakan untuk konsumsi masyarakat sebagai pengganti ikan laut.

\section{Contoh:}

Aek Selan tembus ke Payung

Singgah berenti di Kampong Munggu

Aek banyak gabus dan mayung

Semile nek e....ambik, jen detunggu

\section{Pantun III}

\section{Kayu besi, pelawan, medaru}

Dipakai rakyat membuat alat

Urang kampong selalu bersatu

Gotong-royong memanglah adapt
Mentangor berserak sepulau-pulau

Juga duren, binjai, dan manau

Bagaimana hati takkan tertambat

Melihat indahnya pantai Cupat

Nyiur melambai sepanjang pantai

Sama berjaga bak hutan bakau

Dijajari pelawan, nyatoh, dan petai

Pohon karet pun pemakmur pulau

\section{Mati beragan si batang rumbia}

Buah rambai kusangka rawa

Berangan-angan boleh saja

Kalau tak sampai jangan kecewa

Pantun III menunjukkan bahwa pulau Bangka memiliki begitu banyak tumbuhan/pohon-pohon yang tumbuh dengan fungsi dan manfaatnya masing-masing. Di masyarakat Bangka tumbuh-tumbuhan ini dikenal dengan sebutan "kelekak" yang merupakan simbol dari kekerabatan antar masyarakat pada masa dulu. Kelekak pada dasarnya dapat dibedakan atas dua jenis yaitu kelekak yang ada pemilik sahnya dengan bukti/surat yg berlaku dimana masyarakat mengetahui dan menghormatinya. Jenis ini dapat diwariskan kepada anak cucu si pemilik apabila telah meninggal dunia. Sedangkan kelekak budel/kek antak/antah berentah yaitu jenis kelekak yang tidak diketahui lagi keturunan pemiliknya sehingga kelekak ini dapat dinikmati oleh orang banyak yang masih memiliki hubungan kekerabatan.

Diantara tumbuhan-tumbuhan tersebut ada beberapa jenis yang merupakan sumber mata pencaharian yang menjadi ciri khas masyarakat Bangka sebelum pertambangan dieksploitasi yaitu tanaman lada dan karet. Kedua jenis tanaman ini telah lama dikenal oleh masyarakat setempat yang dulunya mayoritas berprofesi sebagai petani sejak zaman penjajahan. Pekerjaan berkebun merupakan aktifitas sehari-hari yang masih 
banyak dijumpai pada saat itu seperti menyadap getah karet dan menanam lada di ume (kebun/ ladang) yang dilakukan dari pagi hingga sore hari. Pendatang dapat melihat hamparan pohon lada dengan "junjung-junjung" nya serta pohon karet dengan keteraturan cara penanamannya di sepanjang jalan dari desa-desa/kampung menuju kabupaten/kota. Seperti yang tergambar jelas dalam pantun berikut ini:

Dari umah desa pergi ke uma

Juga singgah ke marong sahang

Sambil ngaret, berkebun lada

Sejak Subuh sampai ke petang

Akan tetapi sangat disayangkan semua itu telah berangsur-angsur hilang seperti kelekak atau pepohonan yang telah tergeser posisinya dengan perkebunan kelapa sawit, lahan tambang, dan perumahan.

Selain beraneka ragam tumbuhan/tanaman di atas, masyarakat pulau Bangka juga mengenal salah satu tanaman yang berjenis jamur yang menjadi ciri khas yang dalam istilah mereka dinamakan 'kulat kuku” atau jamur kuku yang biasanya dijadikan sebagai lauk pauk.

Pantun:

Kulat kuku digulai lemak

Batang padi berbelah dua

Biar aku dimarah emak

Asal jadi kita berdua

\section{Pantun IV}

O....pulau orang Lom dan Darat Kau dijaga oleh Sekak dan Juru Sekalipun dirompak Lanun Laknat Tak pernah gentar Cina-Melayu

Kudengar senandung anak Melayu Senandung 'rang Darat, Mapur, dan Sekak Keguyuban orang Lom, Cina, dan Juru

Pendatang pun menyatu penuh sesak
Pantun IV mengungkapkan tentang banyaknya suku atau kelompok masyarakat yang mendiami Pulau Bangka. Dimulai dari zaman masuknya agama Islam di Pulau Bangka dimana pada masa itu terdapat suku terasing yang sudah masuk Islam yang digolongkan sebagai orang Melayu yaitu suku Mapur, sedangkan suku Lom adalah suku yang belum masuk Islam. Variasi penduduk yang terdiri dari beberapa suku menciptakan suatu fenomena yang sangat indah, bagaimana kehidupan yang harus dijalani masing-masing dalam satu kesatuan di Pulau Bangka ini termasuk etnis Tionghoa yang sudah menetap sejak lama.

Menurut data yang dikemukakan oleh Akhmad Elvian (2009) bahwa sebelum agama Islam menjadi agama yang dianut oleh masyarakat Bangka pada sekitar abad 16, penduduk aslinya dikenal dengan sebutan "orang darat" (orang gunung/Hill people) dan "orang laut" (Sea dwellers). Keberagaman ini cukup menarik perhatian para pendatang yang mengunjungi Pulau Bangka tak terkecuali J. Van Den Bogaart seorang pegawai pemerintah kolonial Belanda yang mendeskripsikan suku-suku yang ada menjadi empat kelompok atau grup masyarakat pada tahun 1803 (Heidhues, 1992: 87 dalam Elvian, 2009: 4).

Namun seiiring perkembangan zaman penduduk Pulau Bangka bertambah dengan semakin banyaknya pendatang yang berasal dari latar belakang dan daerah yang berbeda seperti Jawa, Padang, Bugis, Butun, Batak, dll sehingga secara tidak langsung suku asli mulai terusik dan tergeser. Sekarang "orang gunung/orang darat" (komunitas adat masyarakat Mapur) masih tersisa disekitar Gunung Maras, dan "orang laut" yaitu komunitas masyarakat Sekak masih tersisa di wilayah Kedimpel, Tanjunggunung, dan Jebu. Walaupun begitu, keberagaman tersebut tidak- 
lah menjadi halangan bagi masing-masing untuk hidup dalam kerukunan umat yang telah terjalin hingga sekarang seperti yang tampak pada contoh pantun berikut:

Penduduk Bangka campur baur

Bugis, Butun, Melayu, dan Jawa

Saya panjat puji dan syukur

Kedatangan tamu dari penjuru dunia

\section{Pantun V}

\section{Pulau Nek Gergasi dan Akek Antak}

Tempat bertahtanya Gunung Maras

Dimana berkumpul banyak puak

Panorama indah di Pantai Matras

Karoh kerik, karoh akek belapun

Salak asuk terdengar segala peri

Rusa, tunggang, pelandok berhimpun

Seluruh penghuni hidup serasi

Aek Selan tembus ke Payung

Singgah berenti di Kampong Munggu

Aek banyak gabus dan mayung

Semile nek e....ambik, jen detunggu

Banyak jalan lah kenal aspal

Termasok Puding Sangku-Tempilang

Kemana pergi bawalah tangkal

Maklom bahaya Sindai kek Mawang

Karoh kerik berok seutan-utan

Selagi Akek Antak berdendang

Nek Gergasi pun nanek ketan

Ayolah budak ikak berlenggang

Pantun V terdiri dari lima buah pantun yang menggambarkan tentang kepercayaan masyarakat Bangka terhadap hal-hal yang mistis atau supra natural berupa makhluk-makhluk ghaib seperti hantu atau sosok penunggu suatu tempat.
Berdasarkan pantun diatas terdapat beberapa sebutan bagi makhluk-makhluk halus tersebut yaitu Nek Gergasi, Akek Antak (selain nama kelekak), Akek Belapun, Jen (Jin), Sindai, Mawang, dll. Adapun tempat-tempat yang ditunggui adalah kampung, sungai, hutan, bukit, gunung, dan ume (ladang).

Eksistensi makhluk-makhluk ini dianggap sebagai sesuatu yang nyata sehingga para masyarakat setempat sering berpesan agar setiap bepergian jauh atau pada malam hari harus membawa penangkal, sesuatu yang dianggap mampu menghalau makhluk halus untuk mengganggu manusia contoh yang sederhana: gunting, bawang merah bagi ibu-ibu hamil dan bayi/balita, serta bawang merah dan cabai jika ingin membawa pulang makanan terutama yang terbuat dari ketan dan juga buah pisang. Bahkan kedua jenis makanan ini diusahakan untuk dihindari untuk dibawa pada malam hari karena dipercaya dapat mengundang makhluk halus untuk ikut hingga ke rumah, dan itu sangat berbahaya karena ditakutkan makhluk tersebut mengganggu penghuni rumah bahkan ada yang dapat menyebabkan kesurupan. Apabila terjadi hal demikian maka sosok seorang dukon (dukun) diperlukan. Dukon ini disebut dukon kampung yang dianggap dapat mengusir roh dan makhluk halus dengan cepat walaupun menurut agama itu tidak diperkenankan karena masih mempercayai hal-hal yang mistis. Namun, pada kenyataannya memang tidak bisa terpisahkan dari kehidupan masyarakat Bangka. Oleh karena itu, pemahaman mengenai makhluk-makhluk supra natural harus dikaitkan dengan sistem pengetahuan budaya (Steven, 1990: 125 dalam Elvian, 2009: 7), dalam hal ini sistem kosmologi pada suatu masyarakat. 


\section{Pantun VI}

O...Menumbing bukit bersejarah

Penjaga Mentok di pesisir barat

Disini pejuang disekap penjajah

Tapi makin dekat dengan rakyat

Dari Sungailiat ke Puding Besar

Tentulah lewat Pemali dan Sempan

Siang terlihat, malam berpijar

Begitu mercusuar Tanjung Kelian

\section{Gunung Mangkol, Kace, Pedindang}

Sumber aek Rangkui Pangkalpinang

Semua warga haruslah berpantang

Merusak lingkungan hutan larang

Depati Amir pahlawan perkasa

Juga Depati Barin dan Batin Tikal

Semangat kejuangan terus menyala

Sampai kiamat 'kan tetap kekal

Kampung Kurau kampunglah Penyak

\section{Baturusa jerambah besi}

Kami bergurau sambil bertanya

Apa gerangan datang kemari

\section{O...kudengar Puteri bersyair}

"Tak ada lagikah putera gagah

Seperkasa Tikal, Barin, dan Amir

Yang telah membela dengan darah?”

Kumpulan pantun VI ini mengungkapkan bahwa begitu beraneka ragamnya pulau Bangka dilihat dari referensi kunci yang berasal dari kehidupan masyarakat penuturnya. Terdapat kata Menumbing yang merupakan tempat bersejarah dimana Bung Karno diasingkan; Gunung Mangkol, Kace, dan Pedindang yang merupakan sumber mata air bagi sebagian besar masyarakat Bangka terutama yang berada di daerah
Pangkalpinang sekitarnya; kemudian jembatan Baturusa yang menjadi penghubung antara kota Sungailiat dan Pangkalpinang. Menurut kepercayaan terdapat patung rusa hasil kutukan pada zaman dahulu di dalam sungai yang mengalir dibawahnya. Patung tersebut baru dapat terlihat jika air sungai sedang surut.

Selain itu, pulau Bangka juga terkenal dengan mercusuar nya yang berada di kota Mentok (Muntok), Kabupaten Bangka Barat yang berfungsi mengarahkan kapal-kapal yang akan berlabuh atau melewati perairan Mentok. Namun, sangat disayangkan mercusuar tersebut tidak beroperasi lagi sekarang.

Tokoh pahlawan juga menjadi bagian dari sumber inspirasi pemantun dalam kata-kata nya seperti pahlawan-pahlawan yang terkenal di Pulau Bangka yaitu Depati Amir, Depati Barin, dan Batin Tikal yang menginspirasi orang Bangka dalam berjuang mempertahankan hidup dan kehidupannya.

\section{Pantun VII}

Serasi kain denganlah benang

Biar terlipat tidak tergulung

Serasi adik dengan abang

Sejak dirahim Ibu mengandung

Panton VII ini ingin menjelaskan bahwa dalam masyarakat Bangka dikenal dengan kerajinan tangan yang berupa kain tenun yaitu "cual". Walaupun nama tersebut sama dengan kain tenun cual yang berasal dari Palembang namun dapat dibedakan dari motif dan bahannya. Kemiripan ini disebabkan oleh kejadian di masa lampau. Selain sama-sama rumpun Melayu, Bangka dahulu pernah bergabung dalam satu propinsi dengan Palembang. Otomatis secara tidak langsung pengaruh itu pasti ada. Selain kain, pulau Bangka juga memiliki pakaian tradisional yang biasanya digunakan pada acara-acara adat atau perkaw- 
inan dimana baju tersebut berwarna merah seperti baju kurung yang ada di Palembang. Namun, sekarang ini para muda-mudinya tidak terlalu tertarik untuk menggunakannya walaupun di dalam acara sakral. Mereka lebih suka menggunakan kebaya modern karena dianggap lebih simpel dan tidak berat.

\section{Pantun VIII}

Kasut ikak kayu cendana

Kasut kami bertali kain

Maksud ikak nak macam mana

Ape ade maksud yang lain

Akek Saat memikul lapun

Lapun dipikul tenkar masalah

Mintak maaf seribu ampun

Kalok ada cerita salah

Bulan terang turun menyusut

Anak terang habis kesisi

Agik jiat agik keriput

Anak dayang orang habis lari

Budak kampong diam di kebun

Jumahnya beterak dimana saja

Dengan semangat hidup berhimpun

Mereka memecah masalah bersama

Nek Miyak penjaga tanah Tempilang

Kampung besar di Selat Bangka

Menyerah tidak, kalah berpantang

Tanah Maras dibela setiap masa

Kumpulan pantun VIII dari buku pantun Zulkarnain Karim ini (2004) menjabarkan istilah-istilah kekerabatan yang berlaku dalam masyarakat Bangka yang merupakan tanda atau simbol tertentu dari seseorang untuk memanggil kerabatnya. Menurut L.H. Morgan, istilah kekerabatan tersebut digunakan sebagai kunci untuk mengupas semua sistem kekerabatan yang ada di dunia (Koentjaraningrat, 1958: 261 dalam Elvian, 2009: 16). Contoh:

- $\quad$ Akek (Atok/Abok): sebutan untuk orang tua laki-laki dari ayah dan ibu (kakek)

- $\quad$ Nek (Ninek/nenek): sebutan untuk orang tua perempuan dari ayah dan ibu

- Dayang: sebutan untuk perempuan/wanita Bangka terutama bagi yang masih lajang. Dayang juga digunakan sebagai sebutan bagi perempuan/wanita yang terpilih dalam ajang pemilihan puteri Bangka.

- Ikak: sebutan untuk "kalian”, digunakan informal, ditujukan kepada teman sebaya yang sudah dekat atau akrab

- $\quad$ Budak: sebutan untuk anak (informal)

Istilah kekerabatan dalam masyarakat Bangka bervariasi disesuaikan dengan tingkatan kelahiran, atau posisinya dalam keluarga.

\section{Pantun IX}

Teluk Kelabat laut Belinyu

Tampak dari si Tanjung Gudang

Mari sahabat janganlah malu

Menari dambus sambil berdendang

Sebelah sana si Tanjung Ru Jangan lupa ke Teluk Bubus

Ayunkan langkah jangan keliru

Mengiringi lagu irama dambus

Kumpulan pantun IX menceritakan tentang seni tradisional orang Bangka berupa tari dan musik. Hal ini membuktikan bahwa dalam masyarakat Bangka seni mendapat tempat yang penting di kehidupan dan tradisinya. Kata Dambus merupakan nama alat musik petik tradisional Pulau Bangka yang terbuat dari kayu. Alat ini dimainkan dalam bentuk nada dan syair dan digu- 
nakan dalam acara penyambutan, penghormatan, peringatan, hajatan, perayaan upacara, percintaan dan juga acara keagamaan. Tari dan musik dambus biasanya dilakukan pada saat bulan purnama sambil melepas lelah setelah bekerja seharian di ume (ladang/kebun).

\section{Pantun X}

Ayo kawan, ayo seperadik

Kite mancing di laut landai

Beterak ikan perlu ditilik

Siang malam pasti kek ramai

Anak nelayan membuat perahu

Perahu diguna sekuat daya

Wahai sahabat orang Melayu

Jangan hilangkan adat budaya

Pantun X diatas jelas mengungkapkan bahwa mata pencaharian masyarakat Bangka selain berkebun/bercocok tanam dan menambang adalah mencari ikan di laut sebagai nelayan, mengingat Pulau Bangka terletak dan dikelilingi lautan dengan beraneka ragam biota laut yang sangat menunjang perekonomian dan kebutuhan masyarakat.

\section{Pantun XI}

Adat istiadat pula dijunjung

Sedekah ruah dan juga nganggung

Suka duka sama ditanggung

Itu namanya ssenasib sepenanggung

Pantun XI menjabarkan tentang bentuk-bentuk organisasi sosial non-kekerabatan masyarakat Bangka seperti sedekah ruah dan nganggung. Sedekah ruah biasanya untuk menyambut bulan puasa selain dapat dilakukan di rumah juga dapat dilakukan di masjid, surau, atau balai desa dengan menerapkan tradisi nganggung dengan membawa makanan di dalam dulang atau talam terdiri atas nasi lengkap dengan lauk pauknya yang ditutup tudung saji pandan atau daun nipah khas Bangka dengan motif berwarna-warni cerah untuk dimakan bersama. Makanan yang disajikan merupakan makanan terbaik dari masing-masing keluarga. Nganggung juga merupakan kegiatan yang dilakukan masyarakat dalam rangka memperingati hari besar Islam, menyambut tamu kehormatan, acara selamatan orang meninggal, acara pernikahan, atau acara lain yang melibatkan orang banyak. Disebut nganggung karena makanan tersebut dibawa dengan cara di "anggung" (diletakkan di bahu). Namun ada juga yang sudah sedikit modern yaitu menggunakan rantang.

Tujuan adat istiadat/tradisi ini adalah untuk menjaga solidaritas, menghormati orang lain, menunjukkan rasa kepedulian sesama, kebersamaan, gotong-royong, serta menjaga dan menjalin tali kekeluargaan/silahturahim antar sesama yang mencerminkan bahwa manusia itu memanglah sebagai makhluk sosial yang tidak bisa hidup sendiri. Tradisi ini masih akan terasa sekali di daerah pedesaan (kampung).

\section{Pantun XII}

Kampung Mesu simpang delapan

Singgah berenti di rumah Wak Ashar

\section{Orang Mesu rajin, gile maken}

Kuenya habis tujuh pasar

Derite laen ade pule

Kalok sahang jatu harge

\section{Harte bende kok sirne}

Dijual nek buat belanje

Pantun XII menggambarkan tentang bervariasinya makanan yang dijual di Pulau Bangka. Muncul keyakinan bahwa jika ingin mencoba bisnis kuliner di Pulau Bangka maka kualitas dari produk yang dihasilkan harus dapat dipertanggu- 
ng jawabkan. Dengan kata lain, produk tersebut harus memiliki konsistensi terutama rasa. Pada dasarnya orang Bangka senang makan dan mencoba makanan baru. Ketika rasa tidak diprioritaskan, sebagian besar bisnis tersebut tidak akan dapat bertahan atau gulung tikar. Dampaknya akan terlihat dengan cepat karena informasi yang diperoleh akan mudah tersampaikan dari mulut ke mulut sehingga sangat efektif berperan dalam proses jual beli.

Kemudian terdapat satu keunikan lain dari masyarakat Melayu Bangka yang berhubungan dengan keadaan ekonominya yaitu bahwa orang Bangka dikenal dengan sifat konsumtif. Produk dengan harga tinggi juga akan dibeli jika yang bersangkutan menginginkan dan didukung oleh kondisi keuangan yang cukup. Seperti yang diungkapkan dalam pantun diatas yang mengambil contoh kemakmuran masyarakat ketika musim panen lada/sahang terjadi. Mereka sebagian besar berlomba-lomba menghabiskan uang yang diperoleh untuk membeli kebutuhan sekunder seperti motor, mobil, dll. Akibatnya ketika harga lada jatuh, maka dengan terpaksa mereka harus merelakan barang-barang yang dibeli tersebut untuk dijual kembali dengan harga murah demi kelangsungan hidup. Ini merupakan hal negatif yang tercermin dari sebagian besar pola hidup masyarakat Bangka.

\section{Pantun XIII}

Bukan lutung sembarang lutung Lutung meloncat di dahan kayu

Bukan pantun sembarang pantun

Pantun ciri khas budaya Melayu

Pulau Ketawai jauh menengah

Tempat mejumpa naik perahu

Biar bumi terpecah belah

Takkan hilang adat Melayu
Nanem bunga di dalam taman

Untuk hiasan istana puteri

Biar kite dicap kampungan

Asalkan adat dapet lestari

Anak nelayan membuat perahu

Perahu diguna sekuat daya

Wahai sahabat orang Melayu

Jangan hilangkan adat budaya

Kayu besi, pelawan, medaru

Dipakai rakyat membuat alat

Urang kampong selalu bersatu

Gotong-royong memanglah adapt

Budak kampong diam di kebun

Jumlahnya berterak di mana saja

Dengan semangat hidup berhimpun

Mereka memecah masalah bersama

Mendo Barat sumber karet dan lada

Disini berhimpun tulen Melayu

Rakyatnya makmur hidup bahagia

Kaum muslimin pun hidup bersatu

Nek Miyak penjaga tanah Tempilang

Kampung besar di Selat Bangka

Menyerah tidak, kalah berpantang

Tanah Maras dibela setiap masa

Bubus diterpa puting beliung

Anginnya kencang membangun badai

Biar upaya terkadang buntung

Urang Bangka pantang bertikai

Maen di pantai burung kedidi

Pata sayap e ketimpak kayu

\section{Punye adat kek bebudi}

Tula jati diri urang Melayu 
Membakar kayu asap mengepul

Asap mengepul sampai udara

Kalau ikak ingin bergaul

Jangan bergaul cara kota

Nanam padi berpetak-petak

Dapat diluruskan dengan tali

\section{Kami dek suah cigak retak}

Yang penting ikak peduli

Lama aku tertunduk malu sendiri

Kepada diri yang hampir tak berarti

Azan menggamit, klenteng pun bergema

Itulah dia, Pulau Bangka!

Berdasarkan kumpulan Pantun XIII diatas jelas mencerminkan karakteristik dan keunikan Pulau Bangka secara menyeluruh, dimulai dari orang Bangka yang merupakan masyarakat Melayu yang terkenal dengan sopan santunnya baik dalam bertindak maupun bertutur. Tradisi ini sampai sekarang masih terus dilestarikan oleh masyarakat Bangka sebagai simbol kesopanan yang ada. Dinamika kehidupan sosialnya pun berjalan dengan serasi tanpa adanya perpecahan antar kelompok sosial atau antar individu. Masyarakatnya dapat hidup berdampingan saling membantu satu sama lain terutama antara pribumi (Melayu) dan Cina. Hubungan kekerabatannya sangat dekat sekali sejak zaman penjajahan dulu. Oleh karena itu, walaupun Pulau Bangka terdiri dari berbagai macam suku dan latar belakang namun masyarakatnya senantiasa hidup rukun, tenteram, dan damai. Mereka masih menganut adat dengan nilai dan norma yang mengajarkan untuk selalu berbudi luhur. Karakter mereka antara lain pantang menyerah dan suka bergotong royong dalam melakukan sesuatu terutama yang berhubungan dengan kepentingan bersama.

Terdapat satu ungkapan yang sering dika- takan oleh orang Bangka yaitu "dek suah cigak retak" yang artinya tidak peduli apa yang berlaku asal sama-sama bisa menjaga, dalam hal ini dikaitkan dengan situasi yang terjadi di sekitar. Misalnya budaya kota atau barat yang mulai masuk ke kehidupan sosial masyarakat. Orang Bangka tidak akan terlalu ketat dengan perubahan itu asal norma dan adat tetap dijunjung tinggi. Masyarakat menerima segala bentuk perkembangan namun tetap tidak berpaling dari ciri khas yang terpatri sebagai orang Melayu.

\section{KESIMPULAN}

Melalui kajian etnolinguistik terhadap pantun Melayu Bangka selain dapat diketahui bentuk, fungsi, dan struktur gramatikal pantun yang berlaku juga sisi kehidupan sosial masyarakat setempat yang ikut mendukung dan melatar belakangi terbentuknya untaian-untaian kata tersebut.

Bertitik tolak dari hal-hal yang dikemukakan di atas, dapat disimpulkan bahwa lewat pantun sebagai ciri khas orang Melayu, seseorang dapat menyampaikan apa saja seperti isi hati, pengalaman, sosial budaya, dll dengan cara yang halus dan sopan dalam situasi dan keadaan apapun baik itu formal maupun informal walaupun yang ingin disampaikan adalah sebuah protes atau ancaman. Pantun dapat membuat seseorang berpikir logis namun tetap artistik dengan pemilihan diksi yang tepat dan penuh dengan harmonisasi bunyi antar kata-kata tersebut sehingga diharapkan bagi pembaca atau pendengar dapat menikmati dan menelaah makna yang terkandung sehingga benar-benar dapat tersampaikan. 


\section{DAFTAR PUSTAKA}

Arif, R.M.; Nursanto, Suwarni; Gaffar, Z.A; Sulaiman, Mas'ud; dan Saleh,

Yuslizal. 1984. Latar Belakang Sosial Bahasa Melayu Bangka. Jakarta:

Depdikbud Republik Indonesia.

Elvian, Akhmad. 2009. Makalah. Peran Organisasi Sosial Suku Bangsa Melayu Bangka sebagai Kearifan Lokal dan Kekuatan Sosial dalam Penataan dan Pembangunan Masyarakat. Unpublished.

Foley, W.A. 1997. Anthropological Linguistics: An Introduction. UK: Blackwell Publishers Ltd.

Handoko, Yudi. 2012. Lelakaq dalam Budaya Sasak: Analisis Etnolinguistik.

Tesis. Yogyakarta: Universitas Gadjah Mada.

Karim, Zulkarnain. 2004. Pangkalpinang Berpantun. Bangka: Dewan Kesenian Kota Pangkalpinang dan Yayasan Nusantara.

Kridalaksana, Harimurti. 2011. Kamus Linguistik. Jakarta: PT. Ikrar Mandiriabadi

Mihardja, Ratih. 2012. Buku Pintar: Sastra Indonesia. Jakarta: Laskar Aksara.

Nurhayati. 2011. Penggunaan Bahasa dalam Pantun Melayu Bangka: Sebuah Kajian Stilistik. Diakses dari http://nurhayatibizzy. blogspot.com/2011/12/penggunaan-bahasa-dalam-pantun-melayu.html pada tanggal 21 Desember 2012.
Titscher, Stefan; Mayer, Michael; Wodak, Ruth; dan Vetter, Eva. 2009. Metode Analisis Teks dan Wacana. Yogyakarta: Pustaka Pelajar.

\section{Pustaka Laman}

http://jakafilyamma.blogspot.com/2012/06/normal-0-false-false-false-en-us-X-none.html

http://amalina-yuyaa.blogspot.com/2012/06/ definisi-pantun.html 